\title{
Seed productivity and variability of Scots pine (Pinus sylvestris L.) clones of Finnish origin in seed orchard in the central part of Ukraine
}

\author{
Ihor Neyko ${ }^{1} \bowtie$, Olena Kolchanova ${ }^{1}$,Veronika Monarkh ${ }^{2}$, Svitlana Poznyakova ${ }^{3}$ \\ ${ }^{1}$ Ukrainian Research Institute of Forestry and Forest Melioration, Vinnytsia Forest Research Station, Maksymovycha 39, \\ 21036 Vinnytsia, Ukraine, phone: +380 962736367, e-mail: ihor_neyko@ukr.net \\ 2 Vinnytsia National Agrarian University, Sonyachna 3, Vinnytsia, Ukraine \\ ${ }^{3}$ Kharkiv National Agrarian University, Chaikovska 4, 61024 Kharkiv, Ukraine
}

\begin{abstract}
Global climate change has mainly impacted the forest ecosystems in Europe. Today, it is not fully understood how these changes will affect the reproductive process of trees on seed orchards. The main aim of the study is to evaluate the growth, condition and reproductive function of Scots pine clones of Finnish origin after moving them to the southern direction of natural distribution area. Variability and seed productivity of 25-year-old clones of Scots pine of Finnish origin in the clonal seed orchard under climatic conditions of the central part of Ukraine (Vinnitsa region) was investigated. Grafted seedlings of Scots pine of Finnish origin were moved southward at a distance of over 1,500 km. Climatic conditions of Vinnytsia region, where the clones were displaced, differed by an increase in the mean and maximum temperatures by $3.3-3.6^{\circ} \mathrm{C}$, as well as an increase in the mean temperatures during the cold period and a rise in the minimum by $2.1-2.3^{\circ} \mathrm{C}$. The climate in the seed orchard location was characterized by the most significant increase in the mean temperatures in April and May $\left(5.3-5.8^{\circ} \mathrm{C}\right)$, which greatly influenced the intensity of the formation of microstrobili and macrostrobili. The ratio of precipitation to the amount of temperatures decreased more than twice. Analysis of the grafted trees' vitality of Finnish origin and seed progeny of the local population, estimation of their intensity (height, diameter), state (category of the state) and reproductive processes (intensity of formation of microstrobili and cones) was carried out on the clonal seed orchard. In conditions of climate change, most of the clones of Finnish origin were characterized by a higher intensity of flowering compared to the local population. Some clones of Finnish origin (E80 and E729) dominated the local population by the seed yield. According to a comprehensive analysis of vitality, the intensity of growth and reproductive capacity, the best clones of Finnish origin were E80, E1883 and E2254. Low adaptive ability was noted in the clones E2312, K634 and K801. According to the research results, it was found that changes in climatic conditions did not significantly affect the vitality, development and condition of the clones. There was observed intensification of the formation of microstrobili and cones. Seed viability and quality of Scots pine of Finnish origin obtained on seed orchards located in the southern conditions requires further research.
\end{abstract}

\section{KeY WORDS}

Scots pine, seed orchard, clone, health condition, growth, reproduction 


\section{INTRODUCTION}

Seed orchards are one of the main sources for obtaining seeds improved through selection. During the last 50-60 years, seed production in the seed orchards has been intensively developed. Seed orchards of the main forest species have been planted in most European countries. Large areas of seed orchards are concentrated in Sweden, Finland, Poland, Germany, France and other European countries (Giertych 1987; Matyas 1991; Karlsson 1995; Pulkkinen et al. 1995; Crosbie et al. 2003; Lindgren et al. 2008; Nikkanen 2008; Los et al. 2012). Many discussions have been held on the features of the establishment, the number of genotypes, the best methods for growing seed orchards and harvesting seeds (Lindgren et al. 1996; Lstibůrek and El-Kassaby 2010; Torimaru et al. 2011; Rosvall and Lindgren 2012). Despite some controversy, the importance of producing seed orchards is a proven fact in most countries where the forest management is practiced.

The main function of seed orchards is to produce seeds of high genetic quality; therefore, the main goal is to increase the reproductive capacity of trees. Seed productivity of trees in the mast years depends on many factors, in particular, climatic conditions, the influence of biotic agents (Schmidtling 1987; Alizoti 2009; Pulkkinen et al. 2009). Periodicity of tree fruiting is formed at the genetic level, which leads to a repetition of the mast years through certain time periods. Biologicaland-ecological and genetic features of tree species, environmental conditions and the influence of climatic factors are the main factors that determine fruiting frequency and intensity.

Seed orchards, like most forests, are negatively affected by environmental factors. Most of the issues related to the reduction of the adverse effects of biotic factors, including pests, have already been resolved (Annila 1973; Wiersma1978; Brockerhoff et al. 1997; Grosman et al. 2002). In particular, a number of measures are used to successfully control pests and diseases in the seed orchards. At the same time, optimal concepts regarding seed orchard management in the conditions of climate change have not been developed yet. It has not been clarified exactly how climate change will affect the condition of genotypes and their reproductive capacity. It is believed that global climate change, which implies a gradual increase in temperatures in the near future, will not have a significant impact on the seed orchards (Lindgren et al. 2008). Seed orchards will be a more reliable source for seed supply than natural populations. Seed orchards of the 1.5-2 generation established according to the results of testing half-sib and sib progeny under different environmental conditions will be more resistant to climate change (Lindgren et al. 2008).

However, the condition of clones and their reproductive capacity can be influenced not only by global climate changes but to a greater extent by abnormal temperature increase during the growing season, which happens more frequently with global warming. The researches indicate that under the conditions of general temperature increase the intensity of tree flowering will rise. It is noted that the temperature regime and temperature extremes have a significant effect on the formation of reproductive organs (Ilstedt 1982; Sweet 1982). At the same time, seeds grown under the southern conditions may not be suitable for use in the northern regions (Schmidtling 1987). In order to activate seed productivity, most of the Scots pine seed orchards in Finland were located in the southern part of the country. The study of seed progeny obtained from seed orchards showed a decrease in its viability when moved northward (Pulkinen et al. 2009). Therefore, it is believed that seed orchards suffer a significant negative impact due to global climate change (David and Reid 2008).

In this regard, the relevance of the use of seed orchards in terms of global climate change will only increase. Today, the issue of preserving reproductive functions under the conditions of environmental changes remains unresolved. It is important to evaluate both the growth energy in progeny under different environmental conditions and the characteristics of their reproductive capacity. Current progeny tests established under different environmental conditions mainly reflect the changes in the soil fertility and moisture content. In this case, the change in climatic conditions (temperature, precipitation, humidity) is minimal. This limits the prediction of the effects of climatic conditions on reproductive processes. In addition, progeny tests are represented mainly by half-sib progeny that reduces the value of the obtained results.

Therefore, the study of reproductive processes on clonal seed orchards established in different climatic 
conditions is of great interest. Such objects make it possible to simulate the effects of climate change on the reproductive capacity of genetically identical plants. Clonal seed orchards of Scots pine of Finnish origin were established in 1992 in Vinnytsia region (in the central part of Ukraine) by the scientists of the Forest Research Institute of Finland (METLA) and the Vinnytsia Forest Research Station (Ukraine). Similar seed orchards were established in Finland. Today, these are unique objects that enable the investigation of the impact of global climate change on the reproductive processes, condition and features of the development of clones.

\section{Material AND Methods}

The research was carried out in the clonal seed orchard of Scots pine of Finnish origin established in Vinnytsia region (in the central part of Ukraine, N 49 23 '48.71" E 28 7'24.73”) in 1992-1993 according to the scheme of clone placement at $5 \times 5 \mathrm{~m}$. The total area of the seed orchard was 2.0 hectares. Analysis of climatic conditions of the seed orchard location in Ukraine and Finland was carried out using the climate database (https:// www.worldclim.org/). For both locations, we evaluated the differences of such indicators as bioclimatic variables, climate conditions, temperature, precipitation and so on. For both regions of the seed orchard location, we calculated the ratio of precipitation to evaporation, that is, hydrothermal coefficient of Selyaninov (Melnychuk 2018) according to the following formula:

$$
K=R \times 10 / \Sigma t
$$

where:

$K$ - hydrothermal coefficient of Selyaninov,

$R$ - precipitation over the period with temperatures above $+10^{\circ} \mathrm{C}$,

$\Sigma t-$ a sum of temperatures over the period with temperatures above $+10^{\circ} \mathrm{C}$.

We analysed the climatic conditions both in terms of long-term average annual data and long-term average monthly figures. We identified the main differences between these indicators. In the analysis, much attention was paid to the climatic parameters of the growing season, as well as the period of formation of micro- and macrostrobili (April-May).
The study of morphological parameters, health condition and reproductive capacity of 30 Scots pine clones of Finnish origin was carried out during 2012-2018. The clonal seed orchard also included seedlings of Scots pine trees of the local origin, which made it possible to carry out a comparative analysis with the clones of Finnish origin. The crowns of trees located on the clonal seed orchard had not been pruned in the past. This made it possible to measure the morphological parameters of the trees. For each tree, the height, diameter (DBH), crown width and the angle of branching from the central axis of the tree trunk were determined. In this case, standard instruments and tools were used. The DBH of the trees was determined in two mutually perpendicular directions. The crown width was determined in one direction from the west to the east. Statistical calculations, principal component analysis (PCA) were carried out using the R-statistics software.

Intensity of the formation of micro-, macrostrobili and seed yield was determined on the basis of a visual scale of Korchahin (Debrynyk et al. 1998). Studies of clonal seed orchards of Scots pine of Finnish origin were carried out periodically beginning with their establishment in 1993-1999. We regularly assessed their condition, flowering and seed yield since 2012. According to the scale of the intensity of formation of reproductive organs, the following gradations were established: 5 points - a large number of reproductive organs in all branches in the upper and middle parts of the crown $(100 \%$ of the reproductive organs were formed from a potentially possible harvest); 4 points - many reproductive organs on most branches in the upper and middle parts of the crown, especially on the south side ( $80 \%$ of the potentially possible harvest); 3 points - the average number of reproductive organs, evenly or in groups on many branches in the upper and middle parts of the crown, especially on the south side $(60 \%$ of the potentially possible harvest); 2 points - a few reproductive organs on a small number of branches in the middle part of the crown, mainly on the south side ( $40 \%$ of the potentially possible harvest); 1 point - single reproductive organs on separate branches in the upper and middle parts of the crown, mainly on the south side $(20 \%$ of the potentially possible yield); 0 points - there are no reproductive organs. Spatial analysis of the intensity of cone formation was carried out using the R-statistics software. 
Assessment of the health condition of trees was carried out using an improved technique (Volosyanchuk et al. 2003). This technique is based on the Forest Sanitary Rules of Ukraine (https://sfmu.org.ua/en/laws) and the international monitoring method ICP-Forests (Ferretti et al. 2010). For statistical analysis we used the Pearson correlation coefficient (PCC). The PCC was calculated as covariance of the two variables divided by the product of their standard deviations. We used p-value in statistical hypothesis testing, specifically in null hypothesis significance testing (the null hypothesis was rejected when $\mathrm{p}<0.05$ and not rejected when $\mathrm{p}>0.05$ ) (Conover 1999).

\section{Results}

Clonal seed orchard of Scots pine of Finnish origin was established in Vinnytsia region (in the central part of Ukraine) along the southern boundary of the natural area of Scots pine. Grafted seedlings moved southward from Finland to Ukraine at the distance of over $1,500 \mathrm{~km}$ and became the reproductive material.

Grafted seedlings were planted in conditions that differed from their place of origin characterized by temperature regime, precipitation and other environmental characteristics (Tab. 1).

Table 1. Climate condition of Scots pine (Pinus sylvestris L.) clonal seed orchards in Ukraine and Finland (worldclim database)

\begin{tabular}{|l|l|l|c|}
\hline $\begin{array}{c}\text { Bioclimatic } \\
\text { variables }\end{array}$ & \multicolumn{1}{|c|}{ Climate condition } & Ukraine & Finland \\
\hline HWS & Harmonized World Soil & Haplic Greyzems & Haplic Podzols \\
\hline GCOV & Global Land Cover & Water bodies & Water bodies \\
\hline GENS [ID] & Global environment stratification & HS & G9 \\
\hline C & Climatic zone & Cool temperature & Boreal/Alpine \\
\hline E & Environmental zone & Cool temperature and dry & Cold and mesic. \\
\hline AE & Aggregated environmental zones & Cool and dry - HI & Cold moist - EG \\
\hline
\end{tabular}

Table 2. Bioclimatic variables of Scots pine (Pinus sylvestris L.) clonal seed orchards in Ukraine and Finland (worldclim database)

\begin{tabular}{|c|c|c|c|c|}
\hline $\begin{array}{c}\text { Bioclimatic } \\
\text { variables }\end{array}$ & Climate condition & Ukraine & Finland & Difference \\
\hline BBIO1 & Annual Mean Temperature $\left[\mathrm{C}^{\circ}\right]$ & 7.6 & 4 & 3.6 \\
\hline $\mathrm{BIO} 2$ & Mean Diurnal Range (Mean of monthly $\left(\max\right.$ temp $-\min$ temp) $\left[\mathrm{C}^{\circ}\right]$ & 8.7 & 7.7 & 1.0 \\
\hline $\mathrm{BIO} 3$ & Isothermality (BIO1/ BIO7) $(* 100)$ & 26 & 24 & 2 \\
\hline $\mathrm{BIO} 4$ & Temperature Seasonality (standard deviation *100) & 8670 & 8196 & 474 \\
\hline $\mathrm{BIO5}$ & Max Temperature of Warmest Month )) $\left[\mathrm{C}^{0}\right]$ & 24.2 & 20.9 & 3.3 \\
\hline BIO6 & 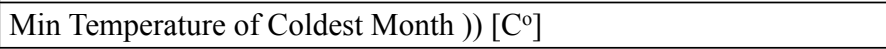 & -8.6 & -10.7 & 2.1 \\
\hline $\mathrm{BIO} 7$ & Temperature Annual Range (BIO5- BIO6) & 328 & 316 & 12 \\
\hline $\mathrm{BIO} 8$ & Max Temperature of Wettest Quarter $\left[\mathrm{C}^{\circ}\right]$ & 16.9 & 13.4 & 3.5 \\
\hline BIO9 & Mean Temperature of Driest Quarter $\left[\mathrm{C}^{\circ}\right]$ & -2.9 & -2.7 & -0.2 \\
\hline $\mathrm{BIO} 10$ & Mean Temperature of Warmest Quarter $\left[\mathrm{C}^{\circ}\right]$ & 18.1 & 14.8 & 3.3 \\
\hline BIO11 & Mean Temperature of Coldest Quarter $\left[\mathrm{C}^{\circ}\right]$ & -3.9 & -6.2 & 2.3 \\
\hline BIO12 & Annual Precipitation $[\mathrm{mm}]$ & 625 & 629 & -4 \\
\hline $\mathrm{BIO} 13$ & Precipitation of Wettest Month [mm] & 93 & 80 & 13 \\
\hline BIO14 & Precipitation of Driest Month [mm] & 31 & 30 & 1 \\
\hline $\mathrm{BIO} 15$ & Precipitation of Seasonality (Coefficient of Variation) [mm] & 38 & 32 & 6 \\
\hline $\mathrm{BIO} 16$ & Precipitation of Wettest Quarter [mm] & 245 & 223 & 22 \\
\hline BIO17 & Precipitation of Driest Quarter [mm] & 102 & 97 & 5 \\
\hline $\mathrm{BIO} 18$ & Precipitation of Warmest Quarter [mm] & 245 & 208 & 37 \\
\hline BIO19 & Precipitation of Coldest Quarter [mm] & 112 & 123 & -11 \\
\hline HTC & Hydro thermic coefficient of Selyaninov & 1.984 & 4.615 & -2.631 \\
\hline
\end{tabular}


Table 3. Monthly climate condition of Scots pine (Pinus sylvestris L.) clonal seed orchards locations in Ukraine and Finland (worldclim database)

\begin{tabular}{|c|c|c|c|c|c|c|c|c|c|c|c|c|c|}
\hline Location & $\begin{array}{l}\text { Monthly climate } \\
\text { condition }\end{array}$ & Jan & Feb & Mar & Apr & May & Jun & Jul & Ago & Sep & Oct & Nov & Dec \\
\hline \multirow{5}{*}{ Ukraine } & Temperature Mean $\left[\mathrm{C}^{\circ}\right]$ & -5.4 & -3.9 & 0.6 & 8.4 & 14.4 & 17.5 & 18.8 & 18.2 & 14.1 & 8.4 & 2.3 & -2.3 \\
\hline & Temperature $\operatorname{Min}\left[\mathrm{C}^{\circ}\right]$ & -8.6 & -7.2 & -3.1 & 3.5 & 8.9 & 12.1 & 13.5 & 12.7 & 8.8 & 4 & -0.5 & -4.8 \\
\hline & Temperature $\operatorname{Max}\left[\mathrm{C}^{\circ}\right]$ & -2.2 & -0.6 & 4.4 & 13.4 & 19.9 & 22.9 & 24.2 & 23.8 & 19.5 & 12.8 & 5.1 & 0.2 \\
\hline & Precipitation $[\mathrm{mm}]$ & 37 & 34 & 31 & 50 & 64 & 88 & 93 & 64 & 49 & 34 & 40 & 41 \\
\hline & HT Coefficient & - & - & - & 1.98 & 1.43 & 1.68 & 1.60 & 1.17 & 1.12 & 1.35 & - & - \\
\hline \multirow{5}{*}{ Finland } & Temperature Mean $\left[\mathrm{C}^{\circ}\right]$ & -6.8 & -7.3 & -3.4 & 2.6 & 9.1 & 14 & 15.9 & 14.7 & 9.7 & 4.7 & -0.4 & -4.4 \\
\hline & Temperature $\operatorname{Min}\left[\mathrm{C}^{\circ}\right]$ & -9.9 & -10.7 & -7.2 & -1.5 & 3.8 & 8.8 & 11 & 10.1 & 6 & 2 & -2.6 & -7.2 \\
\hline & Temperature $\operatorname{Max}\left[\mathrm{C}^{\circ}\right]$ & -3.6 & -3.8 & 0.4 & 6.7 & 14.5 & 19.3 & 20.9 & 19.3 & 13.4 & 7.5 & 1.8 & -1.6 \\
\hline & Precipitation $[\mathrm{mm}]$ & 42 & 31 & 30 & 36 & 38 & 51 & 77 & 80 & 66 & 66 & 62 & 50 \\
\hline & HT Coefficient & - & - & - & 4.62 & 1.35 & 1.21 & 1.56 & 1.81 & 2.20 & 4.68 & - & - \\
\hline \multirow{5}{*}{ Difference } & Temperature Mean $\left[\mathrm{C}^{\circ}\right]$ & 1.4 & 3.4 & 4.0 & 5.8 & 5.3 & 3.5 & 2.9 & 3.5 & 4.4 & 3.7 & 2.7 & 2.1 \\
\hline & Temperature Min $\left[\mathrm{C}^{\circ}\right]$ & 1.3 & 3.5 & 4.1 & 5.0 & 5.1 & 3.3 & 2.5 & 2.6 & 2.8 & 2.0 & 2.1 & 2.4 \\
\hline & Temperature $\operatorname{Max}\left[\mathrm{C}^{\circ}\right]$ & 1.4 & 3.2 & 4.0 & 6.7 & 5.4 & 3.6 & 3.3 & 4.5 & 6.1 & 5.3 & 3.3 & 1.8 \\
\hline & Precipitation [mm] & -5 & 3 & 1 & 14 & 26 & 37 & 16 & -16 & -17 & -32 & -22 & -9 \\
\hline & HT Coefficient & - & - & - & -2.63 & 0.09 & 0.46 & 0.034 & -0.64 & -1.074 & -3.33 & - & - \\
\hline
\end{tabular}
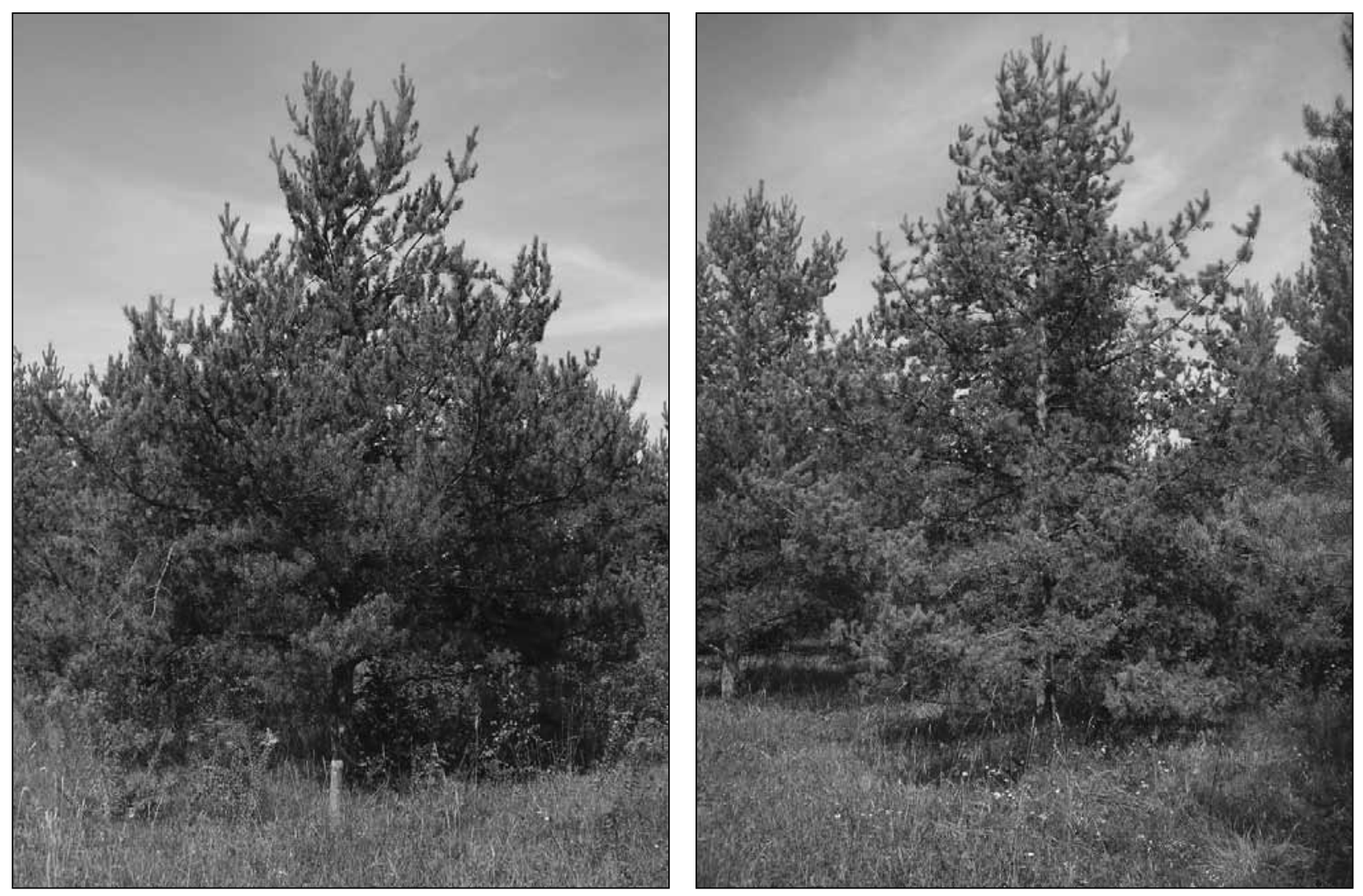

Figure 1. Clonal seed orchard of Scots pine of Finnish origin, Vinnytsia region, Ukraine (photo: Ihor Neyko, 2012) 
New climatic conditions, in which grafted seedlings of Scots pine of Finnish origin were planted, are

Table 4. Characteristic of selected Scots pine plus trees in Finland and graft survival in Ukraine

\begin{tabular}{|c|c|c|c|c|c|}
\hline \multirow[t]{2}{*}{ Clone } & \multirow[t]{2}{*}{$\begin{array}{l}\text { Localization in } \\
\text { Finland (region) }\end{array}$} & \multicolumn{2}{|c|}{$\begin{array}{l}\text { Characteristic } \\
\text { of selected plus } \\
\text { trees }\end{array}$} & \multicolumn{2}{|c|}{$\begin{array}{l}\text { Survival } \\
\text { of grafted } \\
\text { trees in the } \\
\text { seed orchard } \\
\text { in Ukraine }\end{array}$} \\
\hline & & $\begin{array}{l}\text { selec- } \\
\text { tion }\end{array}$ & age & $\begin{array}{c}\text { num- } \\
\text { ber }\end{array}$ & $\%$ \\
\hline E80 & Heinola & 1948 & 95 & 14 & 100.0 \\
\hline E615A & Suomenniemi & 1950 & 108 & 12 & 100.0 \\
\hline E616D & - & - & - & 14 & 100.0 \\
\hline E618 & Suomenniemi & 1950 & 87 & 10 & 100.0 \\
\hline E620 & Suomenniemi & 1950 & 114 & 10 & 83.3 \\
\hline E627 & Sulkava & 1950 & 113 & 13 & 100.0 \\
\hline E636C & Sulkava & 1950 & 81 & 14 & 100.0 \\
\hline E2226 & Mäntyharju & 1964 & 138 & 15 & 100.0 \\
\hline E709 & Ruokolahti & 1951 & 133 & 12 & 92.3 \\
\hline E729 & Sulkava & 1951 & no data & 10 & 90.9 \\
\hline E1591 & Taipalsaari & 1961 & 90 & 10 & 83.3 \\
\hline E1881 & Kerimäki & 1959 & 121 & 13 & 100.0 \\
\hline E1883 & Punkaharju & 1960 & no data & 13 & 92.9 \\
\hline E1944 & Kerimäki & 1963 & no data & 11 & 91.7 \\
\hline E2125 & Kerimäki & 1963 & no data & 13 & 100.0 \\
\hline E2131 & Kitee & 1963 & 110 & 10 & 100.0 \\
\hline E2209 & Punkaharju & 1963 & no data & 14 & 100.0 \\
\hline E2254 & Sulkava & 1963 & 111 & 14 & 100.0 \\
\hline E2257 & Punkaharju & 1963 & 100 & 12 & 80.0 \\
\hline E2312 & Heinola & 1964 & 88 & 8 & 66.7 \\
\hline E2650 & Sysmä & 1965 & 83 & 12 & 92.3 \\
\hline E4039 & Ruokolahti & 1967 & 73 & 13 & 100.0 \\
\hline K294 & Leppävirta & 1952 & 74 & 12 & 92.3 \\
\hline К634 & Tohmajärvi & 1956 & 114 & 11 & 100.0 \\
\hline K795 & Pieksänmaa & 1962 & 86 & 13 & 100.0 \\
\hline К801 & Joroinen & 1962 & no data & 12 & 80.0 \\
\hline К818 & Joroinen & 1963 & no data & 13 & 100.0 \\
\hline K912 & Pieksänmaa & 1963 & 92 & 12 & 92.3 \\
\hline К917 & Pieksänmaa & 1964 & no data & 13 & 100.0 \\
\hline К919 & Pieksänmaa & 1964 & no data & 13 & 100.0 \\
\hline Local & Ukraine, Vinnytsia & & & 13 & 100.0 \\
\hline Total & & & & 391 & 94.8 \\
\hline
\end{tabular}

characterized by higher mean and maximum temperatures by $3.3-3.6{ }^{\circ} \mathrm{C}$, as well as the mean temperatures in the cold period and minimums by $2.1-2.3^{\circ} \mathrm{C}$ (Tab. 2 ).

The increase in the amount of precipitation in Vinnytsia region is the most significant in the dampest year quarter and in the warmest year quarter by 22-37 mm (http://www.eufgis.org/). The ratio of the amount of precipitation to the sum of temperatures by hydrothermal coefficient of Selyaninov in Vinnytsia region is more than twice lower than in the place of plant origin.

The difference in the mean monthly temperatures ranges within $1.4-5.8^{\circ} \mathrm{C}$ being the most significant in April and May $\left(5.3-5.8^{\circ} \mathrm{C}\right)$ (Tab. 3).

In the same months, there are the biggest differences in minimum temperatures $\left(5 \cdot 0-5 \cdot 1^{\circ} \mathrm{C}\right)$. The highest difference of maximums is in April and September $\left(6.1-6.7^{\circ} \mathrm{C}\right)$.

In Finland, monthly precipitation predominates in the late summer and autumn (August-November) (16-32 mm), and in Ukraine, precipitation predominates in the spring months (April-May) (14-37 mm). The value of the hydrothermal coefficient has the greatest difference in two locations (Finland and Ukraine) for the spring (April) and autumn (October). In these months, the ratio of precipitation to the temperatures in Ukraine reduces 2-3 times.

The largest difference in the mean, maximum and minimum temperatures in April-May has a significant impact on the formation of macro- and microstrobilus, as well as on the processes of re-pollination of trees on the clonal seed orchard in Ukraine.

The clonal seed orchard of Scots pine of Finnish origin was established in the spring of 1992. The seed orchard includes 30 clones of Finnish origin and seedlings of Scots pine of the local origin (Fig.1).

Plus trees used to establish a seed orchard are concentrated in the southern part of Finland. The trees K292, K917, K919 had most northern location (Pieksänmaa) (Tab. 4).

Plus trees E80 (Heinola), E1591 (Taipalsaari) had the southern location. About a third of the plus trees were over 100 years old at the time of the cuttings' selection.

Clones of Finnish origin are characterized by high adaptability to environmental changes. Survival of trees on the seed orchard is rather high comprising on 
average $94.8 \%$. This parameter was lowest for the clone E $2312(66.7 \%)$.

The local population had the highest growth intensity in terms of height $(10.6 \pm 5.6 \mathrm{~m})$ (Tab. 5).

Genotype E1883 is characterized by a similar intensity of growth $(10.4 \pm 0.8 \mathrm{~m})$. A local population has the biggest diameters $(29.5 \pm 1.1 \mathrm{~cm})$. Genotypes of Finnish

Table 5. Morphological parameters of pine clones on seed orchard in Ukraine

\begin{tabular}{|l|c|c|c|c|}
\hline Clone & Height [m] & DBH [cm] & $\begin{array}{c}\text { Crown } \\
\text { width [m] }\end{array}$ & $\begin{array}{c}\text { Branch } \\
\text { angle }\end{array}$ \\
\hline E80 & $9.2 \pm 1.0$ & $24.6 \pm 2.6$ & $6.8 \pm 1.2$ & $47 \pm 8.2$ \\
\hline E615A & $7.8 \pm 0.7$ & $20.8 \pm 2.3$ & $5.8 \pm 0.7$ & $48 \pm 8.0$ \\
\hline E618 & $9.7 \pm 1.1$ & $22.2 \pm 3.0$ & $6.4 \pm 0.8$ & $51 \pm 7.0$ \\
\hline E620 & $7.8 \pm 1.1$ & $19.7 \pm 3.3$ & $5.1 \pm 0.9$ & $47 \pm 6.7$ \\
\hline E627 & $8.2 \pm 0.7$ & $18.6 \pm 2.4$ & $5.1 \pm 0.9$ & $48 \pm 6.6$ \\
\hline E636C & $9.1 \pm 0.7$ & $21.8 \pm 2.7$ & $6.4 \pm 1.1$ & $39 \pm 6.7$ \\
\hline E616D & $8.5 \pm 0.7$ & $21.8 \pm 3.1$ & $6.5 \pm 1.4$ & $50 \pm 7.7$ \\
\hline E709 & $7.8 \pm 0.6$ & $18.8 \pm 2.3$ & $6.2 \pm 0.9$ & $49 \pm 6.4$ \\
\hline E729 & $8.8 \pm 0.8$ & $21.2 \pm 2.2$ & $6.6 \pm 1.0$ & $46 \pm 8.2$ \\
\hline E1591 & $7.7 \pm 1.0$ & $17.0 \pm 4.5$ & $5.1 \pm 0.8$ & $41 \pm 10.2$ \\
\hline E1881 & $8.4 \pm 0.6$ & $19.2 \pm 2.6$ & $6.2 \pm 1.3$ & $45 \pm 11.1$ \\
\hline E1883 & $10.4 \pm 0.8$ & $25.7 \pm 1.6$ & $7.1 \pm 1.0$ & $49 \pm 9.4$ \\
\hline E1944 & $8.8 \pm 0.9$ & $21.5 \pm 2.5$ & $5.7 \pm 0.9$ & $41 \pm 6.1$ \\
\hline E2125 & $8.4 \pm 0.5$ & $21.5 \pm 1.8$ & $5.4 \pm 1.2$ & $42 \pm 6.1$ \\
\hline E2131 & $8.2 \pm 0.6$ & $19.3 \pm 0.9$ & $5.2 \pm 1.0$ & $45 \pm 5.9$ \\
\hline E2209 & $9.4 \pm 0.8$ & $27.2 \pm 2.9$ & $7.7 \pm 0.9$ & $40 \pm 6.4$ \\
\hline E2226 & $7.9 \pm 0.7$ & $18.1 \pm 2.7$ & $5.8 \pm 1.4$ & $48 \pm 9.2$ \\
\hline E2254 & $9.1 \pm 0.7$ & $23.5 \pm 4.5$ & $7.1 \pm 1.5$ & $43 \pm 7.5$ \\
\hline E2257 & $8.3 \pm 1.2$ & $19.2 \pm 4.7$ & $5.7 \pm 1.2$ & $51 \pm 8.5$ \\
\hline E2312 & $7.5 \pm 1.2$ & $16.5 \pm 4.2$ & $4.0 \pm 1.5$ & $49 \pm 11.2$ \\
\hline E2650 & $9.4 \pm 0.8$ & $20.3 \pm 2.7$ & $5.9 \pm 1.1$ & $50 \pm 5.4$ \\
\hline E4039 & $9.4 \pm 0.4$ & $21.8 \pm 1.8$ & $5.8 \pm 1.3$ & $49 \pm 5.9$ \\
\hline K294 & $9.0 \pm 0.7$ & $22.5 \pm 2.3$ & $7.2 \pm 1.3$ & $46 \pm 7.9$ \\
\hline K634 & $7.7 \pm 1.0$ & $17.7 \pm 4.1$ & $4.3 \pm 0.7$ & $45 \pm 3.3$ \\
\hline K795 & $7.7 \pm 0.6$ & $20.8 \pm 2.7$ & $4.5 \pm 1.0$ & $43 \pm 6.1$ \\
\hline K801 & $8.1 \pm 1.2$ & $18.0 \pm 4.6$ & $4.5 \pm 1.3$ & $48 \pm 7.2$ \\
\hline K818 & $9.3 \pm 1.1$ & $22.5 \pm 3.4$ & $6.6 \pm 1.2$ & $49 \pm 8.0$ \\
\hline K912 & $8.2 \pm 0.9$ & $19.5 \pm 2.4$ & $5.7 \pm 1.3$ & $41 \pm 7.1$ \\
\hline K917 & $8.0 \pm 0.6$ & $19.6 \pm 3.0$ & $4.5 \pm 0.8$ & $45 \pm 4.1$ \\
\hline K919 & $8.7 \pm 0.9$ & $19.9 \pm 3.4$ & $5.6 \pm 0.7$ & $46 \pm 7.8$ \\
\hline Local & $10.6 \pm 5.6$ & $29.5 \pm 1.1$ & $8.1 \pm 1.4$ & $54 \pm 9.0$ \\
\hline
\end{tabular}

origin, in particular, E2209 $(27.2 \pm 2.9 \mathrm{~cm})$ and E1883 $(25.7 \pm 1.6 \mathrm{~cm})$, are characterized by significant diameters. The local population has also a larger crown width $(54 \pm 9.0 \mathrm{~cm})$. The genotypes E2209 $(7.7 \pm 0.9 \mathrm{~m})$, E2254 $(7.1 \pm 1.5)$ and K294 $(7.2 \pm 1.3)$ have intensive crown development but less than local pines.

By the morphological parameters of trees, the proportion of the first main component is $45.7 \%$. The second and third main components are $20.4 \%$ and $18.7 \%$, respectively. The third and fourth main components comprise the lowest share, that is, $9.7 \%$ and $5.5 \%$, respectively (Tab. 6).

Table 6. PC-analysis of morphological components of pine clones on seed orchard in Ukraine

\begin{tabular}{|l|c|c|c|c|c|}
\hline Traits & PC1 & PC2 & PC3 & PC4 & PC5 \\
\hline Height & 0.5482 & -0.2645 & 0.0954 & -0.5462 & 0.5674 \\
\hline DBH & 0.5877 & -0.1876 & 0.0502 & -0.1173 & -0.7766 \\
\hline $\begin{array}{l}\text { Crown } \\
\text { width }\end{array}$ & 0.5407 & 0.0827 & 0.0339 & 0.7910 & 0.2719 \\
\hline $\begin{array}{l}\text { Branch } \\
\text { angle }\end{array}$ & 0.2062 & 0.4742 & -0.8411 & -0.1582 & 0.0110 \\
\hline $\begin{array}{l}\text { Needle } \\
\text { age }\end{array}$ & 0.1385 & 0.8143 & 0.5290 & -0.1926 & -0.0286 \\
\hline
\end{tabular}

P-value is less than 0.0001 .

According to the analysis of the main components, such indicators as diameter, height, and crown width are characterized by the greatest variability. Their proportion in the structure of the first main component is the highest. Branch angle and needle age have got insufficient variability. The proportion of these indicators is the highest in the second main component. Needle age is characterized by the highest variability in the second main component (Fig. 2).

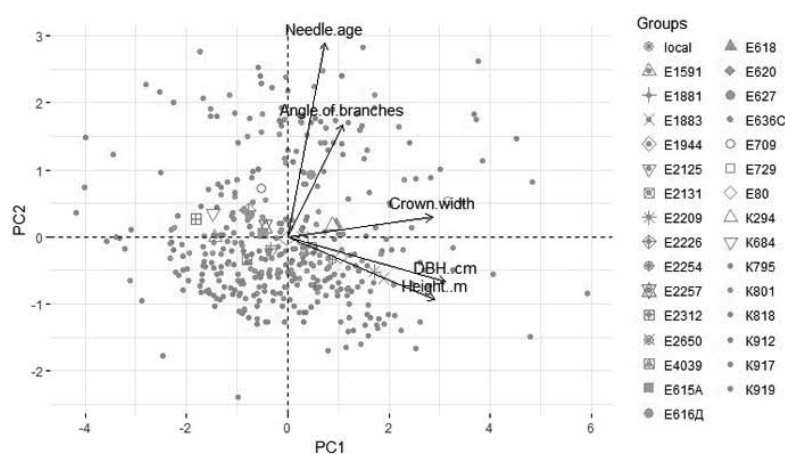

Figure 2. PC-analysis of the main morphological parameters of clones of Finnish origin and local population 
According to results of the correlation analysis, the closest relations have been revealed between tree height and DBH $(\mathrm{r}=0.70)$; DBH and crown width $(\mathrm{r}=0.61)$ (Tab. 7).

Table 7. Correlation components between morphometric parameters of trees, tree health condition and reproductive function of clones on seed orchard in Ukraine

\begin{tabular}{|l|c|c|c|c|c|}
\hline \multicolumn{1}{|c|}{ Trait } & $\begin{array}{c}\text { Height } \\
{[\mathrm{m}]}\end{array}$ & $\begin{array}{c}\text { DBH } \\
{[\mathrm{cm}]}\end{array}$ & $\begin{array}{c}\text { Crown } \\
\text { width } \\
{[\mathrm{m}]}\end{array}$ & $\begin{array}{c}\text { Branch } \\
\text { angle }\end{array}$ & $\begin{array}{c}\text { Needle } \\
\text { age }\end{array}$ \\
\hline Height [m] & 1.00 & 0.70 & 0.49 & 0.10 & 0.05 \\
\hline DBH [cm] & - & 1.00 & 0.61 & 0.15 & 0.07 \\
\hline $\begin{array}{l}\text { Crown } \\
\text { width [m] }\end{array}$ & - & - & 1.00 & 0.21 & 0.18 \\
\hline $\begin{array}{l}\text { Branches } \\
\text { angle }\end{array}$ & - & - & - & 1.00 & 0.06 \\
\hline Needle age & - & - & - & - & 1.00 \\
\hline
\end{tabular}

The average category of Scots pine clone health condition is 1.5 points. Clones E80, E627, E2125 and the local population were characterized by the best condition (1.2-1.3). Clones E4039, K912, K917A had a significantly lower average category of health condition (1.8).

The intensity of microstrobili formation in clones varies over the years from 2.5 to 4.5 points and averages 3.9 points (Fig.3).

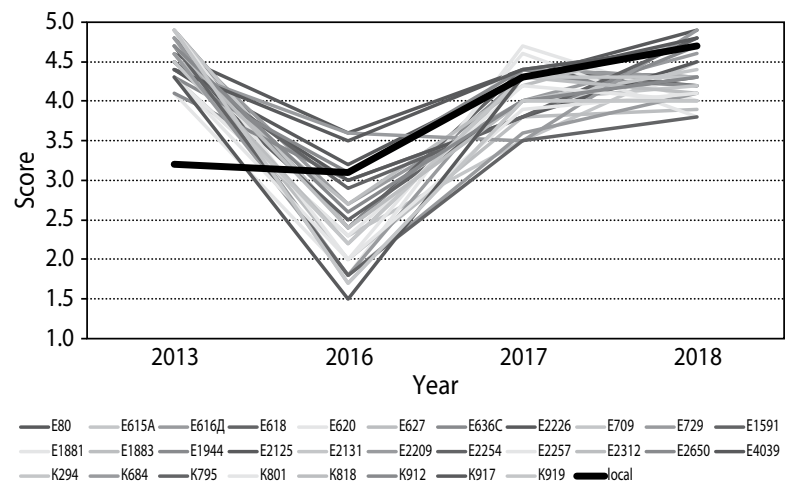

Figure 3. Flowering (microstrobili) dynamics of Scots pine clones on seed orchard in Ukraine

Maximum intensity of microstrobili development was revealed in 2013. During the next two years, the intensity of the formation of male reproductive organs de- creased. In the local population, the intensity of microstrobili formation was lower than that of some Finnish clones, especially in 2013. During most of the years, the dynamics of microstrobili development in Scots pine of Finnish origin and the local population were synchronous. During the last 5 years, clones E80, E2226 and E2209 had the highest intensity of formation of male reproductive organs. The average score of microstrobili development in these clones was 4.2-4.3. The average intensity of microstrobili development in the local population scored 3.8 .

The highest intensity of development of the 2-yearold pine cones was recorded in 2017 (2.5 points) (Fig.4).

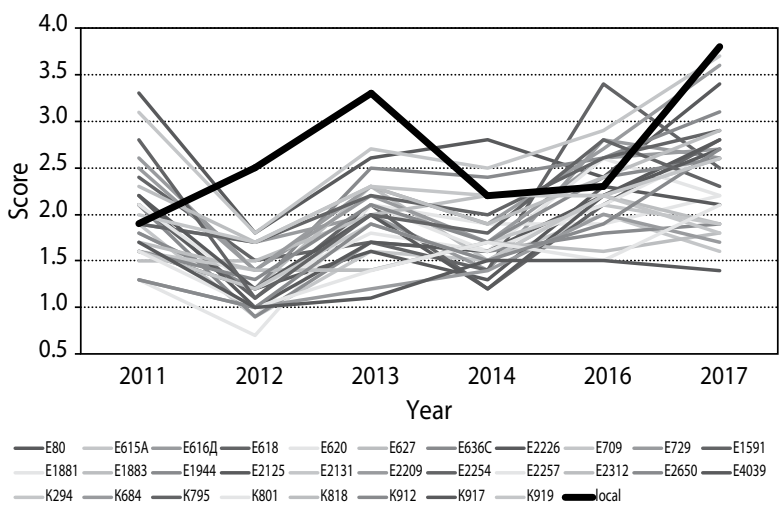

Figure 4. Dynamics of 2-years Scots pine cones on the clonal seed orchard in Ukraine

Enhancement of the reproductive capacity of clones tended to increase. During the last 6 years, the average seed yield was the highest in clone E80 and in the local population (2.7-2.8 points). Clone E80 retained high reproductive capacity throughout most years of research. In 2011, 2014, and 2016, a significant share of Finnish clones had higher seed productivity than the local population. The intensity of cone formation in Scots pine of Finnish origin and a local population was synchronous in 2013, 2014 and 2017. Clone E618 had an extremely high reproductive capacity in 2016 (3.4 points).

Spatial analysis indicates the regularity of the appropriate placement of clones on the seed orchards and the intensity of seed yield (Fig. 5).

In particular, the clones characterized by high seed yield had a high score of seed yield almost in all parts of the seed orchard. Low seed yield was registered mainly in the clones that were located in the cen- 

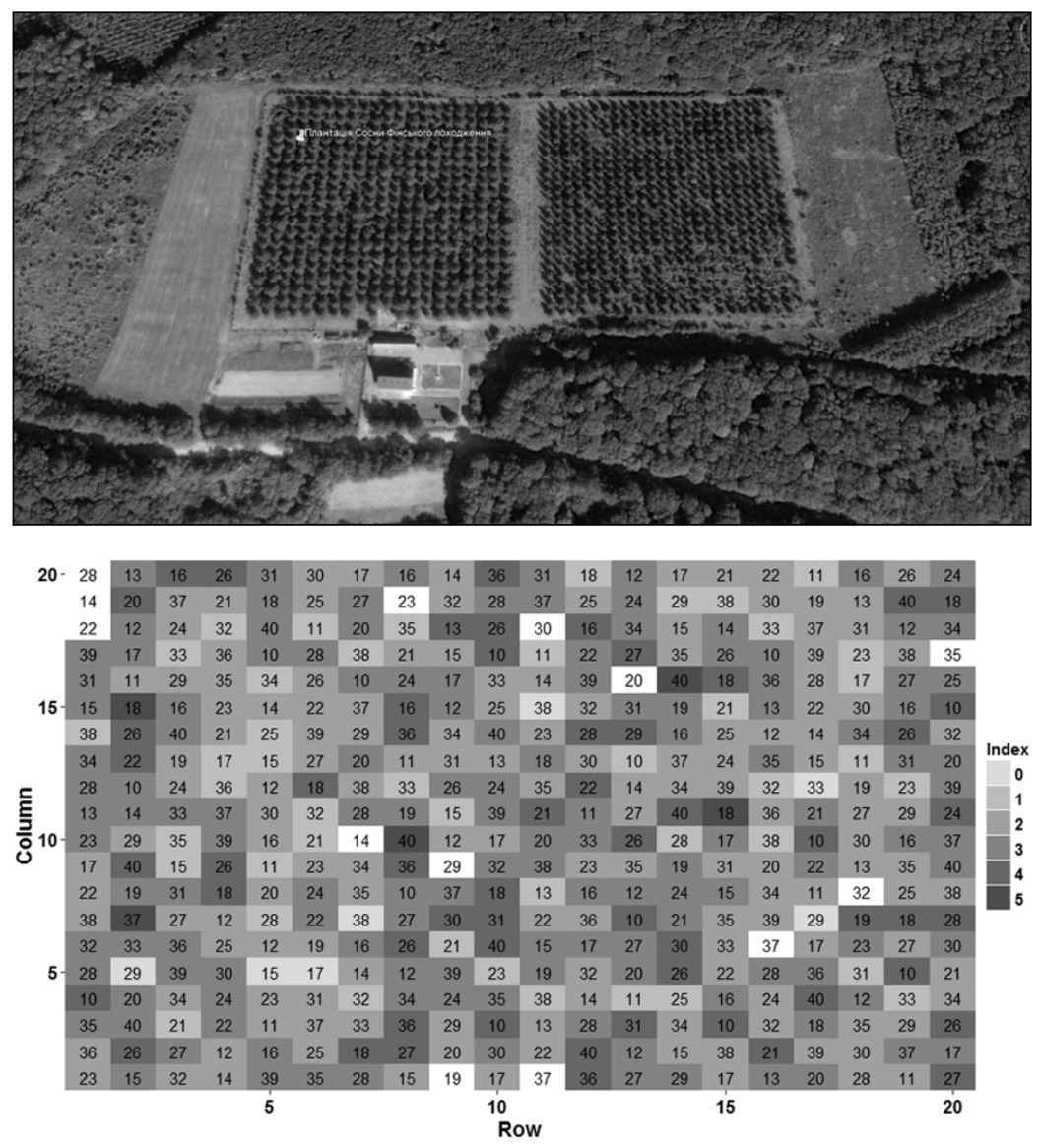

Figure 5. Spatial distribution of the seed yield of Scots pine on clonal seed orchard in Ukraine (on the top satellite image; below - seed yield intensity)

tendencies. The condition of clones K912 and K917 was considerably worse (average category of the condition was 1.8).

Tree growth, development, health condition and reproductive processes are the main indicators of the adaptation of clones under conditions of climate change. Such traits of trees as survival, diameter, height, health condition, the formation of microstrobili and cone have been used for a comprehensive assessment of the successful adaptation. According to the comprehensive assessment of genotypes, the local population was characterized by the highest rank (the total score was 13). The clones of Finnish origin E80, E1883, E2254 and E618 were characterized by very high indices (the total score was 24-35 points) (Tab. 8).

The clones of Finnish origin E1591, K801, K634, and E2312 had the lowest ranks (the total score was 103-112). In the overall assessment structure, most clones of Finnish origin dominated over the local population by the rate of microstrobili de-

tral part of the seed orchard. On the periphery of the site, most of the clones were characterized by a high score of cone formation. Clones characterized by low seed yield (E615A, E627, E2226, K216) had substantially higher seed yields on the periphery of the seed orchard. This indicates an increase in the fruiting of clones having a low rate of cone formation under the increase in the sunlit surface.

During 2012-2018, the average category of the clone condition ranged within $1.3-1.7$ points.

This reflects the mean value of the crown defoliation and discoloration at the rate of $0-30 \%$. During this period, a slight deterioration in the health condition of the clones was registered. Clones E80, E627 and E2125, as well as the local population, were in the best condition (the average category of the condition - 1.2-1.3). While most clones and the local population were deteriorating in 2014, clone E80 showed some improvement velopment. Clones E80 and E729 had higher or similar seed productivity compared to the local population. Clones E615A and K917 were characterized by the lowest reproductive capacity for the development of microstrobili and cones.

\section{Discussion}

The research on the effectiveness of afforestation using seed orchards under conditions of global climate change is of great importance due to ensuring the stability of forest seed production in the future. According to our studies, the increase in mean and maximum temperatures will not significantly reduce the growth energy, health condition and reproductive capacity of the Scots pine clones in the seed orchards. It confirms the opinion concerning the insignificant impact of global climate 
Table 8. Ranking of clones according to morphological parameters and reproductive function

\begin{tabular}{|c|c|c|c|c|c|c|c|c|}
\hline Clone & 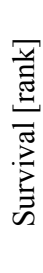 & 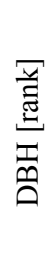 & 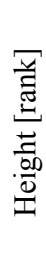 & 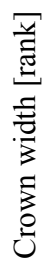 & 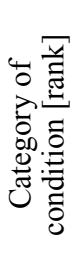 & 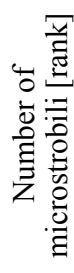 & 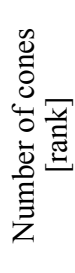 & 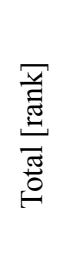 \\
\hline E80 & 1 & 4 & 8 & 6 & 2 & 2 & 1 & 24 \\
\hline E615A & 1 & 15 & 26 & 16 & 3 & 7 & 12 & 80 \\
\hline E618 & 1 & 8 & 3 & 11 & 3 & 4 & 5 & 35 \\
\hline E620 & 1 & 19 & 25 & 26 & 5 & 4 & 4 & 84 \\
\hline E627 & 6 & 26 & 19 & 24 & 4 & 7 & 10 & 96 \\
\hline E636C & 1 & 9 & 9 & 10 & 2 & 8 & 9 & 48 \\
\hline E616D & 1 & 10 & 15 & 9 & 4 & 5 & 3 & 47 \\
\hline E709 & 1 & 25 & 27 & 13 & 4 & 2 & 10 & 82 \\
\hline E729 & 3 & 14 & 13 & 7 & 3 & 5 & 2 & 47 \\
\hline E1591 & 5 & 30 & 29 & 25 & 3 & 6 & 5 & 103 \\
\hline E1881 & 6 & 23 & 16 & 12 & 5 & 6 & 6 & 74 \\
\hline E1883 & 1 & 3 & 2 & 5 & 4 & 6 & 7 & 28 \\
\hline E1944 & 2 & 13 & 12 & 18 & 4 & 3 & 7 & 59 \\
\hline E2125 & 4 & 12 & 17 & 22 & 4 & 5 & 10 & 74 \\
\hline E2131 & 1 & 22 & 21 & 23 & 1 & 5 & 7 & 80 \\
\hline E2209 & 1 & 2 & 4 & 2 & 5 & 6 & 9 & 29 \\
\hline E2226 & 1 & 27 & 24 & 17 & 3 & 3 & 4 & 79 \\
\hline E2254 & 1 & 5 & 10 & 4 & 4 & 4 & 4 & 32 \\
\hline E2257 & 7 & 24 & 18 & 19 & 6 & 7 & 8 & 89 \\
\hline E2312 & 8 & 31 & 31 & 31 & 3 & 6 & 10 & 120 \\
\hline E2650 & 3 & 17 & 6 & 14 & 4 & 3 & 8 & 55 \\
\hline E4039 & 1 & 11 & 5 & 15 & 7 & 1 & 7 & 47 \\
\hline K294 & 3 & 6 & 11 & 3 & 6 & 6 & 9 & 44 \\
\hline K634 & 1 & 29 & 28 & 30 & 5 & 9 & 10 & 112 \\
\hline K795 & 1 & 16 & 30 & 28 & 3 & 9 & 8 & 95 \\
\hline K801 & 7 & 28 & 22 & 29 & 6 & 8 & 10 & 110 \\
\hline K818 & 1 & 7 & 7 & 8 & 6 & 6 & 5 & 40 \\
\hline K912 & 3 & 21 & 20 & 20 & 7 & 5 & 9 & 85 \\
\hline K917 & 1 & 20 & 23 & 27 & 7 & 7 & 11 & 96 \\
\hline K919 & 1 & 18 & 14 & 21 & 5 & 7 & 5 & 71 \\
\hline Local & 1 & 1 & 1 & 1 & 1 & 6 & 2 & 13 \\
\hline
\end{tabular}

change on the functioning of seed orchards (Lindgren et al. 2008). In order to increase seed productivity, most of the pine seed orchards in Finland have been located in the southern part of the country (Pulkinen 1995, 2009).

The data we have received indicate good survival and development of most clones of Finnish origin under conditions of climate change. We have not observed a significant deterioration in the health condition of clones of Finnish origin compared to the local population.

The intensity of microstrobili development in the Finnish clones in most cases is higher than in the local population. This coincides with the findings of scientists who argue that the movement of trees southward increases the intensity of their flowering (Ilstedt 1982; Sweet 1982). Special attention is paid to the clones of Scots pine of Finnish origin (E80, E729), which are characterized by similar or higher seed productivity than the local population. We have collected seed material and carried out a series of controlled re-pollinations with the pollen of Finnish and Ukrainian origin. However, we have not received the final data on the seed quality and viability, as well as growth energy of progeny. We expect that the seed quality of the clones of Finnish origin obtained under the conditions of Vinnytsia region will be lower than on the seed orchards located in Finland.

In general, genotypes can respond differently to the changes in climatic conditions. In our case, there have been identified a number of clones, which appeared to be more stable (E80, E1883, E2254) and less stable (E2312, E1591, K636, K801) under the conditions of environmental change. Less resistant genotypes have low survivability, energy growth, and seed yield. To assess the interaction of the genotype-environment and to carry out the imperative analysis, data of seed orchards established in Finland is necessary. The data on the energy growth and reproduction intensity will enable us to identify more accurately the Scots pine's response to global climate change.

According to the analysis, it can be concluded that global climate change will have a minor effect on the functioning of pine clonal seed orchards in the near future. The energy of clone growth and their condition will not undergo significant changes, while reproductive processes may be activated. The intensity of microstrobili and cones' development is likely to increase, 
and seed production may increase. At the same time, the quality of the formed seed may deteriorate. In its turn, it may result in the reduction of survivability and growth energy of the progeny. The quality of seeds obtained under the conditions of climate change, as well as features of the viability and growth of progeny still remain to be issues that require further research.

\section{Conclusion}

25-year-old clones of Finnish origin retained high adaptive ability in the seed orchards under conditions of climatic changes. The increase in the mean and maximum temperatures by $3.3-3.6^{\circ} \mathrm{C}$, as well as the increase in the mean temperatures in the cold period and the minimums by $2.1-2.3^{\circ} \mathrm{C}$ and reduction of the ratio of precipitation to the temperatures twice, did not lead to deterioration of their condition and growth energy. Under the change in climatic conditions, clones of Finnish origin retained high reproductive capacity. The intensity of microstrobili development in most clones of Finnish origin was higher than that of the local population.

According to the evaluation of survivability, growth and development energy, as well as reproductive processes, such clones of Finnish origin as E80, E1883, E2254 and E618 differed by the best characteristics. The ranking of these clones by these indicators was the highest. The lowest adaptive ability was observed in clones E1591, K801, K634 and E2312. The lowest intensity of the formation of micro strobilus and cones was observed in clones E615A and K917.

\section{References}

Alizoti, P., Kilimis, K., Gallios, P. 2009. Temporal and spatial variation of flowering among Pinus nigra Arn. clones under changing climatic conditions. Forest Ecology and Management, 259 (4), 786-797.

Annila, E. 1973. Chemical control of spruce cone insects in seed orchards. Communicationes Instituti Forest Fenniae, 78, 1-25.

Brockerhoff, E.G., Kenis, M. 1997. Strategies for the biological control of insects infesting coniferous seed cones. In: 5th cone and seed insects working party conference (eds.: A. Battisti, J.Turgeon), Sep- tember 1996, Monte Bondone, Padova. University of Padova, Italy, 49-56.

Conover, W.J. 1999.Chapter 3.4: The Sign Test. In: Practical nonparametric statistics (Third ed.). Wiley, 157-176.

Crosbie, T.M. et al. 2003. Plant breeding: Past, present, and future. In: Hallauer International Symposium proceedings Plant breeding (eds.: K. Lamkey, M. Lee), 17-23 August 2003, Mexico City. Blackwell, Oxford, UK, 1-50.

David, J.S., Reid, R.P.F. 2008. British Columbia's seed orchard program: multi species management with integration to the end user. In: Conference proceedings Seed orchard (ed.: D. Lindgren), 26-28 September 2007, Umeå, Sweden, 88-94.

Debrynyk, Yu., Kalinin, M., Huz, M., Shabliy, I. 1998. Forest seed production. Svit, Lviv, Ukraine.

Establishment of a European information system on forest genetic resources (EUFGIS). 2019. Available at http://www.eufgis.org/

Ferretti, M., Fischer, R., Mues, V., Granke, O., Lorenz, M. 2010. Basic design principles for the ICP Forests Monitoring Networks. Manual Part II. In: Manual on methods and criteria for harmonized sampling, assessment, monitoring and analysis of the effects of air pollution on forests. UNECE ICP Forests Programme Co-ordinating Centre, Hamburg.

Giertych, M. 1987. Seed orchards in crisis. Forest Ecology and Managament, 19 (1/4), 1-7.

Grosman, D., Upton, W., McCook, F. 2002. Systemic insecticide injections for control of cone and seed insects in loblolly pine seed orchards -2 year results. Southern Journal of Applied Forestry, 26, 146-152.

Ilstedt, B. 1982. Seed production in Nordic seed orchards. Swedish Agricultural University. Research Notes, 35.

Karlsson, B., Rosvall, O. 1995. Breeding programmes in Sweden. Skogforsk, Arbetsrapport, 302.

Lindgren, D., Karlsson, B., Andersson, B., Prescher, F. 2008. Swedish seed orchards for Scots pine and Norway spruce. In: Conference proceedings Seed orchard (ed.: D. Lindgren), 26-28 September 2007, Umeå, Sweden, 142.

Lindgren, D., Matheson, A. 1986. An algorithm for increasing the genetic quality of seed from seed or- 
chards by using the better clones in higher proportions. Silvae Genetica, 35 (5/6), 173-177.

Lindgren, D., Gea, L., Jefferson, P. 1996. Loss of genetic diversity monitored by status number. Silvae Genetica, 45 (1), 52-59.

Los, S.A. et al. 2014. State of forest genetic resources in Ukraine. Planeta-Print, Kharkiv, Ukraine.

Lstibůrek, M., El-Kassaby, Y.A. 2010. Minimum-inbreeding seed orchard design. Forest Science, 56 (6), 603-608.

Matyas, Cs. 1991. Seed orchards. Developments in Plant Genetics and Breeding, 3, 125-145.

Melnychuk, S. 2018.Meteorology and climatology (in Ukrainian). Lviv, Ukraine.

Nikkanen, T. 2008. A review of Scots pine and Norway spruce seed orchards in Finland. In: Proceedings from a conference Seed orchard (ed.: D. Lindgren), September 26-28 2007, Umeå, Sweden.

Pulkkinen, P., Haapanen, M., Mikola, J. 1995. Effect of southern pollination on the survival and growth of seed orchard progenies of northern Scots pine ( $P i$ nus sylvestris) clones. Forest Ecology and Management, 73 (1/3), 75-84.

Pulkkinen, P., Varis S., Pakkanen, A., Koivuranta, L., Vakkari, P., Parantainen, A. 2009. Southern pollen sired more seeds than northern pollen in southern seed orchards established with northern clones of Pinus sylvestris. Scandinavian Journal of Forest Research, 24, 8-14.
Rosvall, O., Lindgren, D. 2012. Inbreeding depression in seedling seed orchards. In: Proceedings of conference Seed orchards and breeding theory (ed.: N. Bilir), 21-25 May 2012, Antalya, Turkey, 52-59.

Sanitary Rules in the forests of Ukraine. 2016. Ruling of October 26, 2016. № 756 on amendments to resolutions of the Cabinet of Ministers of Ukraine dated July 27, 1995. № 555 and from May 12, 2007. № 724 (in Ukrainian). Available at http://sfmu.org. ua/en/laws/

Schmidtling, R.C. 1987. Locating pine seed orchards in warmer climates: benefits and risks. Forest Ecology and Management, 19 (1/4), 273-283.

Torimaru, T., Wennström, U., Lindgren, U., Wang, X-R. 2011. Effects of male fecundity, interindividual distance and anisotropic pollen dispersal on mating success in a Scots pine (Pinus sylvestris) seed orchard. Heredity, 108 (3), 312-321.

Volosyanchuk, R.T. et al. 2003. Methodical approaches to the estimation of objects of conservation of the gene pool of deciduous tree species in situ and their present state in the left-bank forest-steppe of Ukraine (in Ukrainian). Forestry and Agroforestry, 104, 50-57,

Wiersma, N. 1978. Cone and seed insects in Europe. In: Proceedings of symposium Flowering and seed development in trees, 15-18 May 1978, Mississippi State University, 291-304.

WorldClim - Global Climate Data. 2019. Available at https://www.worldclim.org/ 